This item was submitted to Loughborough's Research Repository by the author.

Items in Figshare are protected by copyright, with all rights reserved, unless otherwise indicated.

\title{
Mixing drink and drugs: 'underclass' politics, the recovery agenda and the partial convergence of English alcohol and drugs policy
}

\section{PLEASE CITE THE PUBLISHED VERSION}

http://dx.doi.org/10.1016/j.drugpo.2016.02.005

\section{PUBLISHER}

(C) Elsevier

\section{VERSION}

AM (Accepted Manuscript)

\section{PUBLISHER STATEMENT}

This work is made available according to the conditions of the Creative Commons Attribution-NonCommercialNoDerivatives 4.0 International (CC BY-NC-ND 4.0) licence. Full details of this licence are available at: https://creativecommons.org/licenses/by-nc-nd/4.0/

\section{LICENCE}

CC BY-NC-ND 4.0

\section{REPOSITORY RECORD}

Monaghan, Mark P., and Henry Yeomans. 2019. "Mixing Drink and Drugs: 'underclass' Politics, the Recovery Agenda and the Partial Convergence of English Alcohol and Drugs Policy". figshare. https://hdl.handle.net/2134/21321. 


\section{Accepted Manuscript}

Title: Mixing Drink and Drugs: 'Underclass' Politics, the Recovery Agenda and the Partial Convergence of English Alcohol and Drugs Policy

Author: Mark Monaghan Henry Yeomans

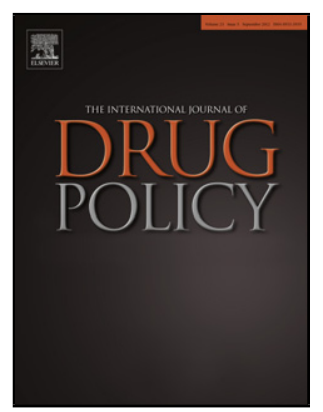

PII:

S0955-3959(16)30013-5

DOI: http://dx.doi.org/doi:10.1016/j.drugpo.2016.02.005

Reference: DRUPOL 1724

To appear in: International Journal of Drug Policy

Received date: 26-10-2015

Revised date: 20-1-2016

Accepted date: $5-2-2016$

Please cite this article as: Monaghan, M., and Yeomans, H.,Mixing Drink and Drugs: 'Underclass' Politics, the Recovery Agenda and the Partial Convergence of English Alcohol and Drugs Policy, International Journal of Drug Policy (2016), http://dx.doi.org/10.1016/j.drugpo.2016.02.005

This is a PDF file of an unedited manuscript that has been accepted for publication. As a service to our customers we are providing this early version of the manuscript. The manuscript will undergo copyediting, typesetting, and review of the resulting proof before it is published in its final form. Please note that during the production process errors may be discovered which could affect the content, and all legal disclaimers that apply to the journal pertain. 


\section{Highlights for Review}

The criminal law upholds a 'great regulatory divide' separating the licit trade in alcohol from the illicit trade in substances classified as either class A, B or C under the Misuse of Drugs Act 1971. This article, however, makes explicit comparison of recent policy developments used to govern alcohol and illicit drugs in England. ${ }^{1}$

Consideration of the idea of a convergence between policies governing alcohol and illicit drugs in England through the lens of the recovery agenda.

Analysing the relevance of Berridge's long term historical argument to policies enacted by UK governments over the last 20 years, which pays specific attention to the re-emergence of abstinence in both alcohol and drugs policy.

Examining whether the relevant policies of the New Labour Government (1997-2010) and the Coalition Government (2010-2015) to question whether the dividing line of the criminal law necessarily means that all public policies relating to alcohol are distinct in form and unrelated in practice from those which affect illicit drugs.

\footnotetext{
${ }^{1}$ Laws and policies governing alcohol and drugs in Scotland and Wales are distinct from those in England and are not examined here.
} 


\title{
Mixing Drink and Drugs:
}

\section{'Underclass' Politics, the Recovery Agenda and the Partial Convergence of English Alcohol and Drugs Policy}

Dr Mark Monaghan, School of Sociology and Social Policy, University of Leeds, UK Dr Henry Yeomans, School of Law, University of Leeds, UK

\begin{abstract}
Alcohol policy and illicit drugs policy are typically presented as separate and different in academic discussion. This is understandable, to a degree, as the criminal law upholds a 'great regulatory divide' (Seddon, 2010: 56) separating the licit trade in alcohol from the illicit trade in substances classified as either class A, B or C under the Misuse of Drugs Act 1971. This paper takes a different stance. In doing so, it draws upon Berridge's (2013) argument that policies governing various psychoactive substances have been converging since the mid-twentieth century and seeks to elaborate it using recent developments relating to the control and regulation of drugs and alcohol in the broader areas of criminal justice and welfare reform. Significantly, the article examines how recent policy directions relating to both drugs and alcohol in England have, under the aegis of the 'recovery agenda', been connected to a broader behavioural politics oriented towards the actions and lifestyles of an apparently problematic subgroup of the population or 'underclass'. The paper thus concludes that, although the great regulatory divide remains intact, an underclass politics is contributing towards the greater alignment of illicit drugs and alcohol policies, especially in regards to the respective significance of abstinence (or abstinence-based 'recovery').
\end{abstract}

Key Words,

Drugs, Alcohol, Policy 


\section{Mixing Drink and Drugs:}

\section{'Underclass' Politics, the Recovery Agenda and the Partial Convergence of English Alcohol and Drugs Policy}

\section{Introduction}

Where policy is concerned, academic discussion of alcohol and illicit drugs frequently emphasises their disparities. As Bennett and Holloway (2005:3) have commented, alcohol research and drugs research tend to be conducted by different groups of researchers and the resultant literatures do not regularly overlap. It is quite normal for research on drugs policy to be framed in regards to the divide between licit and illicit substances, or to make reference to alcohol and the (usually) more permissive policies which govern its consumption and trade, but more detailed comparison is rare. This is understandable, to a degree, as the criminal law upholds a 'great regulatory divide' (Seddon, 2010: 56) separating the licit trade in alcohol from the illicit trade in substances classified as either class A, B or C under the Misuse of Drugs Act 1971. But, in spite of this legal divide, there is a strong basis for a more comparative focus. Alcohol is usually understood to be a psychoactive and potentially addictive 'drug'. Ever increasingly, its use has been connected to a broad array of social harms and, although disaggregating harms deriving from substance use from those deriving from the policy frameworks regulating substance use is challenging (see Rolles and Measham, 2011), its relative harmfulness has been compared to that of illicit drugs (Nutt et al, 2007 and 2010). These similarities suggest that, while unusual, it is feasible to compare social and political responses to the consumption of various licit and illicit substances. 
One of the few academic studies which attempts this is Virginia Berridge's recent book Demons. This book examines the historical development of various expert discourses on alcohol, illicit drugs and tobacco, and considers the connections between these discourses and public policy. Importantly, Berridge's novel argument suggests that, despite some sharp historical divergences, subsequent shifts in understanding mean that policy responses to various substances, especially alcohol, illicit drugs and tobacco, may have moved closer together since the mid-20 $0^{\text {th }}$ century (Berridge, 2013). The "great regulatory divide" is seen by Berridge, not as monolithic and impermeable, but as nuanced and subject to historical change. This article picks up on Berridge's line of analysis and considers its connections to a broader behavioural politics, oriented towards the actions and lifestyles of an apparently problematic subgroup of the population or "underclass", which has emerged from around the 1980s onwards (e.g. Murray, 1984; 1996a; 1996b). Political interest in an underclass is visible in various countries, notably Britain and the USA. The convergence in understandings highlighted by Berridge (2013), moreover, is identified within various Western countries as well as the actions of transnational bodies such as the World Health Organisation. While both central phenomena have a transnational dimension, this paper examines their relevance to some recent developments in alcohol and drugs policies in England. Specifically, the article considers how policy directions relating to both drugs and alcohol have, under the aegis of the recovery agenda, been connected to ongoing efforts to regulate the behaviour of an apparent underclass. The idea of historical convergence is thus investigated in respect to more recent policy developments in Englandi. 
To do this, the article assesses the relevant policies of the New Labour Government (1997-2010) and the Coalition Government (2010-2015) and provides some preliminary comments on the directions adopted by the current Conservative Government (2015+). It examines key drugs and alcohol policy documents and considers the political discourse in which these have been framed. The article does not investigate policy implementation or impact, but instead concentrates primarily on the discursive level with a view to identifying how relevant policies concerning alcohol and illicit drugs are framed by central government. We maintain that analysing the framing of policy can be revealing with regards to comprehending how certain behaviours and social groups are constructed as problematic and how political interventions which target them are rationalised. The first section of the article outlines Berridge's analysis of the historical divergence and convergence of policies relating to alcohol and illicit drugs as well as introducing the notion of the underclass. We then discuss the recovery agenda, particularly with its initial focus on abstinence (Monaghan, 2012; Wardle, 2012; Duke, 2013). Here we acknowledge a schism between policy discourse and policy practice, but also suggest that via heightened conditionality, the 'recovery' of welfare claimants and offenders, often considered to be part of the underclass, is pursued more than that of other groups. It is in this scenario, we conclude, that a degree of convergence in alcohol and drugs policy is apparent.

\section{Historical Divergence and Convergence}

Berridge (2013) argues that a series of divergences and convergences have helped produce the discursive and regulatory situation that exists with regards to alcohol and drugs today. The most striking historical divergence is the advent of the "great regulatory divide" around the time of the First World War. The use of alcohol was 
legally restricted but widely practised in the Victorian period. Opium, and increasingly cannabis and cocaine, were also legally available and largely socially acceptable in the nineteenth century (Berridge, 2013: 15). However, Britain committed to drug control by signing the 1912 Hague Convention and, after concerns about inappropriate use of cocaine during wartime and significant pressure from the USA, enacted the Dangerous Drugs Act in 1920. The Act criminalised possession (without a prescription) of opium, cocaine and other substances designated as 'dangerous' and, as such, is often identified as the beginning of prohibitionist drugs policy in Britain (Seddon, 2010; Barton, 2011: 13-19). Successive British governments rejected the idea of alcohol prohibition. Although a number of Western countries did prohibit alcohol in the 1910s and 1920s, these policies were fairly short-lived. (Schrad, 2010). By the mid-1900s, it was normal for Western countries to prohibit a group of illicit drugs and permit the trade and consumption of alcohol.

Following Berridge's (2013) argument, the second historical juncture of relevance is a growing acceptance from the mid-twentieth century onwards of drugs as a psychoactive, addictive category of substances which includes alcohol alongside opium, cocaine and other illicit substances. The emergence of this unified conception of licit and illicit drugs was tied to the interplay between two contrasting models for understanding addiction: the disease model and the public health model. The disease model suggests that addiction can be explained as a deficit or malady affecting the individual user. Some users of opium were diagnosed with the disease of addiction in the early 1900 s and this diagnosis came to be, across the early to mid-twentieth century, also applied to those who could not control their use of other substances, such as cannabis and alcohol (Levine, 1978, Valverde, 1998, Berridge, 2013). The public-health model rose to prominence from the 1950 s onwards and, in 
contrast to the disease model, places more emphasis on the psychoactive and addictive properties of substances themselves. Its objectives relate less to the treatment or cure of individual addicts and more to a desire to reduce or manage the harmful consequences of various substances at a population level (Thom, 1999). Importantly, the public health model also advanced the notion that, because they share some properties and harmful social effects, alcohol and many illicit drugs were essentially similar. It is in this sense that Berridge (2013) identifies a process of convergence within expert discourses on alcohol and illicit drugs from the midtwentieth century onwards.

To an extent, Berridge links this convergence within expert discourses on psychoactive substances to some policy changes. For example, she examines how some harm reduction policies in the 1980 s, such as methadone prescription and the creation of safe needle exchanges, can be linked to the wider influence of the public health model (Berridge, 2013: 188-212). But is this historical narrative of convergence evident within other, more recent policy developments? Initially, the answer might seem to be a resounding no. The UK Government's response to new psychoactive substances (see Stevens and Measham, 2014), and its recent rejection of a petition calling for the legalisation of cannabis (UK Government, 2015), have reaffirmed its ongoing commitment to prohibitory drugs policies. Simultaneously, there are no signs that current or future UK governments will have any interest in prohibiting alcohol. But, while the total, legal convergence of alcohol and drugs policies has clearly not occurred and is highly unlikely to occur in the foreseeable future, the long history of divergence and convergence in how different substances are understood and regulated suggests that the possibility of some form or extent of convergence should not be discounted entirely. 
With a view to extending the debate around policy convergence, it is important to observe that much of the convergence that Berridge identifies occurs at a similar time to the emergence of the notion of an underclass. This notion is rooted in the work of Charles Murray who, in the 1980s, used the term to denote a sub-group of poor people. Importantly, while the underclass are poor, he argues that they are not defined by their poverty but 'defined by their behaviour' (Murray, 1996a: 23). Crime, unemployment and illegitimate births are singled out as the main characteristics of the underclass but drunkenness, poor schooling and unkempt homes are also identified as typical (Murray, 1996a). Murray's thesis was not unprecedented and echoed, for example, Victorian concerns about the 'criminal class'. Nevertheless, it has resonated within political discourse on various social problems, particularly those relating to work and employment (see Bauman, 1998). Amongst those who accepted the main tenets of Murray's thesis was Labour MP Frank Field (Field, 1996). Field places added emphasis on the structural factors which have contributed to the apparent creation of an underclass and he has been instrumental in advancing a 'politics of behaviour' (Field, 2003) which, by asserting common standards of "decency" or notions of "civility", is intended to remedy some of the problems arising from the underclass (Bottoms, 2006, Crawford, 2010). The notion of an underclass is, therefore, closely linked to the diagnosis of poor behavioural standards among certain social groups and a perceived need for political solutions to this problem (Prideaux, 2010).

The notion of the underclass did not arise in expert discourses about substance misuse, such as the disease and public health models, but in political discourse. Interestingly, however, it does locate various social problems, including some substance use problems, within a sub-group of 'the poor' rather than within 
individuals or whole populations. Building on this observation, the remainder of this article assesses how some degree of recent convergence is apparent in how certain drugs and alcohol policies have, under New Labour (1997-2010) and Coalition (2010-2015) governments, focused upon, and been shaped by, wider efforts to govern the apparently problematic behaviour of an underclass.

\section{The Recovery Agenda}

The 2010 Drug Strategy, has at its core a desire to see so-called problematic drug and alcohol users undergo a 'permanent change' and come off drugs and alcohol for good. In doing so, they can 'successfully contribute to society', which can be understood as entering the paid labour market (UK Government, 2010:18). It is perhaps best encapsulated by the growing political discontent over methadone maintenance treatment as a key pillar of previous drug strategies. Indeed, the shift away from methadone prescription (in rhetoric at least [see McKeganey, 2014]) was implicit in the sub-title of the 2010 National Drugs Strategy Supporting People to Lead a Drug Free Life (UK Government, 2010). The 2013 evaluation of this strategy proudly claimed that 'record numbers of people in England are completing their treatment free of dependence' (UK Government, 2013: 8). At the outset, the Coalition strategy continued themes developed in the previous Labour Government strategy (UK Government, 2008) by re-valorising abstinence-based approaches to drug treatment in both drugs and alcohol. This trend has become known as the recovery agenda (Monaghan, 2012, Wardle, 2012; Duke, 2013).

Although in the foreword to the 2010 drugs strategy, the Home Secretary Theresa May cites both drug and alcohol dependence as 'key causes of societal harm, including crime, family breakdown and poverty' (UK Government, 2010: 2), the 
recovery agenda has primarily concerned drug use. There has, however, been a parallel movement towards abstinence within alcohol policy discourse in recent years as public health professionals have emphasised that no amount or form of alcohol consumption is categorically safe. In 2009, Chief Medical Officer Liam Donaldson stressed that, in regards to the development of certain serious health conditions, 'there is no safe alcohol limit' (Donaldson, 2009a) and, in 2016, his successor Sally Davies stated that 'the risk of developing a range of illnesses... increases with any amount you drink on a regular basis' (Department of Health, 2016: 2). With all alcohol consumption regarded as risky, the Government's guidance on advisable drinking levels, first issued in 1987, has been challenged and qualified. In 2009, under-15s were advised to abstain from alcohol entirely (Donaldson, 2009b) and, in 2012, it was recommended that adult drinkers should have several drink-free days per week (Science and Technology Committee, 2012). Furthermore, in 2016, the recommended weekly limit for male alcohol consumption was revised downwards from 21 units to 14 (Department of Health, 2016). Notably, despite a lack of evidence that change was needed, guidance given to pregnant women was amended in 2006 . The old advice that women who were pregnant or trying to conceive should limit their drinking to one or two units once or twice per week was also replaced with a stipulation of abstinence (Lowe and Lee, 2010).

Increasingly, therefore, public health discourses have identified abstinence, rather than reduced consumption, as the best way to avoid risk (and thus harm) for dependent and, in some circumstances, non-dependent substance users. This shift has impacted on the form of addiction or dependence treatment encouraged by central government and the official advice provided about alcohol consumption levels. The promotion of abstinence-based treatment or recommending styles of 
drinking close to abstinence do not, in and of themselves force any changes in behaviour. Greater leverage is, however, applied to some groups through welfare and criminal justice approaches and it is in these spheres that further mixing of drink and drugs policies are apparent.

\section{Conditionality in welfare and work}

In the UK, from around 2008 onwards, drugs policy has become firmly embroiled in a more wide-ranging debate over austerity with reduced public spending on social security in the vanguard. The Coalition Government made varied attempts to tackle a perceived "something for nothing culture" which has allegedly emerged amongst the unemployed in Britain according to various Government actors. It has been pointed out how promoting abstinence to reduce "worklessness" has become a mainstay of UK drugs policy since around 2008 (Monaghan and Wincup, 2013). Indeed, government ministers' rhetoric has persistently associated worklessness with drug use and vice versa. Work and Pensions Minister lain Duncan-Smith, has frequently asserted that drug users need to change their behaviour and start looking for paid work, stating that, 'The outdated benefits system fails to get people off drugs and put their lives on track...we want to do more to encourage and support claimants into rehabilitation for addiction, starting them on the road to recovery and eventually work' (BBC News, 2012).

The journey into work for unemployed drug users is a cornerstone of the recovery agenda. This thinking was prominent in much Coalition discussion around drugs, but its origins can be traced back to the New Labour drug strategy of 2008 :

We do not think it is right for the taxpayer to help sustain drug habits when individuals could be getting treatment to overcome barriers to employment. 
So, we will explore the case for introducing a new regime which provides more personalised support than that which is currently provided...In return for benefit payments, claimants will have a responsibility to move successfully through treatment and into employment. (UK Government, 2008: 6)

The idea of denying or reducing welfare payments to recipients who appear to have a drink or drug problem but refuse treatment has been repeatedly floated by both New Labour and the Conservatives (e.g. BBC News, 2009; Wintour, 2015). New Labour legislated for the removal of welfare payments from drug users who do not either seek work or undergo treatment but the relevant provisions were never enacted (Wincup, 2011). The Coalition developed similar policies. Under the Work Programme, jobseekers are required to agree and sign a Personal Action Plan which requires them to undertake certain activities (Department for Work and Pensions [DWP], 2013). Similarly, applying for the Coalition's Universal Credit (created by the Welfare Reform Act 2012) involves signing a Claimant Commitment which includes various conditions relating to work-seeking activities. In both cases, failure to comply with these conditions can lead to sanctions, such as the reduction or removal of benefits.

Under the current Conservative administration (2015+) Claimant Commitments and Personal Action Plans are now widely used. Because of their individualised nature, it is difficult to gauge their precise form or impact. Early indications suggest that benefit sanctions are being used mainly to punish failure to actively look for work or non-attendance at scheduled meetings (Newton et al, 2012, DWP, 2015) rather than to coerce welfare recipients into treatment or abstinence. Interestingly, while benefits sanctions do not yet appear to have imposed in relation to drinking or drug use directly, Wincup (2014) notes that the US, New Zealand and 
other countries have taken a similar policy path by increasingly using welfare reform to manage substance use. The association of drug use with worklessness and the concomitant push towards conditionality appears to be a transnational policy trend (which, in the UK at least, pertains to alcohol use also). Given this broad policy direction and the routine identification of drug and alcohol problems as 'barriers to work' (Newton et al, 2012: 1, DWP, 2013), it is reasonable to suppose that conditions relating to treatment and abstinence from drugs or alcohol may play a larger part in welfare provision in England in the near future. Even as things stand, Newton et al (2012) do raise concerns that welfare recipients with complex problems, including alcohol or drug dependence, are not being provided with appropriate support on the Work Programme.

There is, therefore, a tangible risk that, within a changing welfare landscape, those with complex problems of addiction or dependence may not receive adequate support and could be penalised if they fail to attend meetings or meet other conditions of their welfare payments. Wakeman (2015) demonstrates as much in his ethnographic study of heroin use and users in post-industrial northern England, but shows how some of the impacts of this conditionality are offset by the specific social bonds that exist between members of this particular disadvantaged group. That said, one potential consequence of these broader policy shifts is that some forms of treatment could be enforced on welfare recipients through conditionality. In pushing through these reforms, the Coalition continued New Labour's policies in which problem drinkers or drug users are regarded as a legitimate target for behavioural interventions (see: Harrison and Sanders, 2014). Wincup (2014) explains that this intervention through conditionality is tied to two policy agendas. Firstly, it ties to wider efforts to improve the economy and public finances by increasing employment levels 
and moving people off welfare benefits. The second agenda concerns an expanding use of conditionality within the benefits system as a "stick" with which to force socalled problematic populations to address their behaviours. This latter task also occupies the criminal-justice system.

\section{Conditionality and criminal justice}

As within the welfare system, there is increased congruity in how problem drinkers and drug users are dealt with in the criminal justice system. Particularly, there are now a myriad of ways in which conditions can be applied to problematic alcohol or drug users when they are processed by the criminal-justice system. Indeed, several New Labour reforms have been said to represent the "criminalisation" of UK drugs policy whereby policy and practice, particularly around treatment, was less about providing welfare to the drug user and more about reducing the prevalence of drugrelated crime (Duke, 2006; Seddon et al, 2008). Using legislation, emphasis was placed on fusing the treatment and enforcement strands of drug policy. This partly occurred through an expansion in the capacity of authorities to attach treatment conditions to bail if suspects are thought to have drug problems as well as through the growth of arrest referral schemes for both drug and alcohol (mis)users (Hopkins and Sparrow, 2006; Hucklesby et al, 2007, Hancock et al., 2012). Notably, it has also occurred through the increased power of criminal courts to attach conditions pertaining to either drug or alcohol use to sentences. Drug Treatment and Testing Orders (DTTO) were created by the Crime and Disorder Act 1998 and probably marked the start of this new form of sentencing. Subsequently, the Criminal Justice and Court Services Act 2000 created Drug Abstinence Orders (DAOs) and Drug Abstinence Requirement (DARs). Reuter and Stevens (2007) explain how these were community based sentences allowing authorities to test offenders for drug use. 
DARs could only be given if the court believed drug dependence was linked to an offender's behaviour and the said offender agreed to a programme of treatment. DAOs were not designed for those considered to be 'addicted' and did not compel the offender to seek treatment, but were meant to be employed in situations where there was 'sufficient concern' about an offender's risk of drug misuse to justify ongoing monitoring (House of Commons Library, 2012).

DTTOs, DAOs and DARs were all phased out after the Criminal Justice Act 2003 created Drug Rehabilitation Requirements (DRRs), which entail the treatment and testing of offenders in circumstances where an offender's apparent drug dependence is linked to their offending and they are willing to comply. The same Act also created Alcohol Treatment Requirements (ATRs) which, although they cannot force an individual to undergo alcohol testing, impose conditions similar to DRRs on alcohol dependent offenders (see McSweeney, 2014). Although some measure of alcohol-related conditionality could be applied previously under the Powers of Criminal Courts Act 2000, the 2003 reform marked a much clearer alignment of the means through which courts can respond to alcohol or drug dependant offenders.

Since 2003, the most notable development with regards to sentencing has been the creation of Alcohol Abstinence and Monitoring Requirements (AAMRs) by the Legal Aid, Sentencing and Punishment of Offenders Act 2012. This Act provides for courts to ban offenders from consuming alcohol for up to 120 days if the court believes that their drinking contributed to the commission of their offence(s). The key characteristics of this provision are that it is specifically not to be used for offenders who are dependent on alcohol, cannot be accompanied by any compulsion to seek treatment and does not require an offender's consent to be applied. It appears to be aimed at people who commit crime after drinking but are not considered alcoholics. 
Although it is feasible that AAMRs will have some short-term preventative function in regards to offending, these characteristics make them appear rather punitive, especially in comparison with the (formally) voluntary conditions of testing and treatment applied by DRRs or ATRs. Compliance with AAMRs will be monitored by "sobriety bracelets" which are worn by offenders and continually test the alcohol content of a person's sweat. This means of enforcement again seems more stringent than the regular blood or urine tests which underpin other treatment-based requirements of community sentences. AAMRs are currently being piloted but their national implementation has already been promised by the Conservative Government (Alcohol Policy UK, 2015).

Conditionality in sentencing has thus expanded the extent to which offenders' drug or alcohol use is governed by criminal justice processes. Various conditions are imposed in an effort to alleviate problems of dependence, reduce re-offending and perhaps intensify the level of punishment that can be imposed on offenders. Interestingly, and in line with the recovery agenda, this conditionality can sometimes involve abstinence. It must be noted that the behaviours targeted by drugs and alcohol policies are still somewhat distinct. Crucially, there is no form of illicit drug use which is constructed as permissible in official policy discourse; all drug use must be tackled (see UK Government, 2010). While all drug use is thus constructed as a legitimate target for intervention, the new drinking interventions discussed in this section and the previous one only concern alcohol consumption related to dependence or offending. This situation mirrors the wider political discourse in which forms of drinking deemed excessive and irresponsible are roundly condemned, but other forms of drinking are permissible and perhaps even positive due to their apparent economic benefits or links to personal sociability (UK Government, 2012: 
3). Although public health groups increasingly argue that all drinking is problematic (as discussed earlier), the Government's continued deviation from this view means that important differences in drugs and alcohol policies remain. These differences do not, however, diminish the wider point of this section. Sentencing conditions, like welfare conditions, now apply very similarly to drugs and alcohol.

\section{Problematic behaviours of problematic populations}

With conditionality in welfare and criminal justice targeting alcohol and drug users alike through a valorisation of abstinence, we are left with the task of explaining these trends. It is important to identify that those targeted by conditionality tend to belong to the more disadvantaged socio-economic groups. Obviously, the Work Programme and Universal Credit are welfare policies which are designed to deal with people who are out of work or on low incomes. Criminal justice interventions do not explicitly target lower socio-economic groups in the same manner, although it is fairly well-established that they do tend to concern these groups more than others (e.g. see Sutherland, 1940, Braithwaite, 1981, Wacquant, 2009, Prison Reform Trust, 2013). Importantly, this means that interventions designed to tackle problematic forms of drinking and drug use that operate through welfare and criminal justice processes are very likely to affect poorer people more than wealthier people. This governmental imbalance might be defensible in light of evidence that individuals with drug problems tend, as far as can measured, to be concentrated in number within poor, high crime areas (Seddon, 2006, Reuters and Stevens, 2007). Alcoholism, however, does not appear to vary by income (McManus et al, 2009) and average drinking actually seems lower amongst poorer people than wealthier people (Health and Social Care Information Centre, 2013). So, alternatively, it is worth considering whether the measures described in the previous section might be 
understood in relation to the underclass as a means of "punishing the poor" (Bauman, 1998, Wacquant, 2009).

It is notable that many of the welfare and criminal justice policies discussed in the previous section have been rationalised in a manner that is broadly consistent with the idea that a problematic social sub-group is being targeted. The pioneering creation of DTTOs in 1998, for example, is usually attributed to government efforts to cut the link between problem drug use and persistent offending. As Turnbull et al explained, it was increasingly clear that a "relatively small group of problem users imposes heavy costs on both victims of crime and public services... including those incurred by the criminal justice, social security and health systems" (1998: 1). The 2010 Drugs Strategy strikes a similar chord in stressing that "the vast majority of adults do not take drugs" before setting out a range of reforms targeting the (apparent) minority who do (UK Government, 2010: p.5). Similarly, when launching the Government's Alcohol Strategy 2012, Theresa May explained that "We all know there is a significant minority in this country who drink dangerously and who cause disproportionate harm" as part of her explanation for a raft of reforms including the piloting of AAMRs (Home Office, 2012). London Mayor Boris Johnson, moreover, positioned the pilot of AAMRs as a way to protect the "law-abiding majority" from "alcohol-fuelled criminal behaviour" (The Guardian, 2014). In all examples, problem drinking and drug use are located within groups who exist somewhere outside of the societal mainstream.

While the term "underclass" itself is not frequently used in contemporary political rhetoric, it is common for ministers to identify a sub-group of poor people whose unacceptable behaviour is connected to many social problems. Former Prime Minister Tony Blair, for example, attributed the 2011 riots to a 'group of young, 
alienated, disaffected youth who are outside the social mainstream and who live in a culture at odds with any canons of proper behaviour' (Blair, 2011). Importantly, this alienated, disaffected sub-group are often associated with drug use and drink problems. In reference to the same riots, Prime Minister David Cameron explained that:

...we've known for years that a relatively small number of families are the source of a large proportion of the problems in society. Drug addiction, alcohol abuse, crime. A culture of disruption and irresponsibility that cascades through generations... Last year the state spent an estimated $£ 9$ billion on just 120,000 families...that is around $£ 75,000$ per family. (Cameron, 2011)

Similarly, at the 2010 Conservative party conference, lain Duncan-Smith the Work and Pensions Secretary stated "Most people in this country don't wake up early in the dark and cold, and head to their job in order for the state to take their money and waste it. They don't slump, exhausted in their chair after work, just to see their taxes spent on people who can work but won't... (cited in Patrick, 2012). In 2014, this was followed up with an announced plan to replace cash payments to some benefit claimants with pre-paid cards (BBC News, 2014). The rationale for this planned policy was expressed in reference to the aim of reducing benefit claimants' expenditure on drink and drugs. So senior political figures tend not only to identify a demographic subgroup of anti-social, work-shy, offending welfare recipients; they also seek to associate this subgroup with behavioural problems of drug-use and alcohol abuse.

Of course, public or political mobilisation against drinking or drug use is not new or unusual. Drug use has been identified as a typical target of moral panics (Jewkes, 2011) and alcohol has been a central historical target for moral regulation 
projects (Yeomans, 2014). But, importantly, Cameron and Duncan Smith's rhetoric illustrates that drug use and forms of drinking deemed excessive are now designated as characteristics or signifiers of an immoral or problematic social sub-group.

Consequently, the conditionality mechanisms of certain reforms, particularly welfare and criminal justice changes, have increasingly associated drinking and drug use with unemployment and poverty as well as offending. These substantive policy changes are thus mirrored by dominant political discourse in which excessive drinking and drug use are frequently constructed as characteristic of a specific social sub-group who are apparently responsible for many societal problems. In political discourse, the (mis)use of psychoactive substances is thus among the behaviours used to help delineate an underclass and construct them as a benefit claiming, offending "other".

\section{Conclusion}

This paper has analysed illicit drugs and alcohol policies relating to an underclass with a view to exploring Berridge's (2013) idea of a convergence between government policies on certain psychoactive substances. It has examined a range of policies which have been followed by New Labour, the Coalition and, in a preliminary sense, the current Conservative Government. Of course, alcohol and illicit drugs policies remain separated by the thick line of the criminal law. But either side of this divide, the policies used to govern drinking and drug use in England have, in some respects, become mixed together. This ongoing change has been evidenced, firstly, through the decline of harm reduction and the re-valorisation of abstinence in regards to addiction and health through the recovery agenda; and, secondly, through the related proliferation of treatment and/or abstinence conditions within the welfare 
and criminal justice systems. These two policy trends have been specifically examined because of the way in which they have been directed towards, and shaped by, a wider political concern for the behaviour of an apparent underclass.

This paper has used government policy and rhetoric to connect developments across drugs and alcohol policy to this evolving governmental interest in regulating the behaviour of a problematic demographic subgroup whose behaviour is increasingly seen to be characterised by drug use and excessive drinking as well as worklessness and offending. As such, the recovery agenda's abstinence rhetoric can also be seen as connected to a wider politics of behaviour that has become embedded in contemporary practices of government.

By comparing illicit drugs policy to alcohol policy, and considering both in reference to wider social policies, this paper has provided a different perspective on the recovery agenda. This has occurred, firstly, by linking it to a wider behavioural politics in the manner already described. Secondly, and partly because of the mutual links of drugs and alcohol policies to this behavioural politics, it has been contended that the recovery agenda should be understood as historically situated in the sense that it has contributed to the continuation of an older process of convergence in some aspects of how alcohol and drugs are understood and regulated. Broad support for Berridge's idea of policy convergence has therefore been found.

Finally, the authors hope the paper demonstrates the utility of research that addresses policies relating to different psychoactive substances comparatively rather than separately. The processes of policy convergence here identified would not have come into such sharp focus if different psychoactive substances were examined in 
isolation from each other or as distinct groups of licit and illicit substances. Of course, there are many substances which have not been discussed here, including prescription drugs, new psychoactive substances, tobacco and e-cigarettes. There are also some policy areas, such as education, which have been omitted from this discussion. There is, therefore, significant potential for further comparisons of government policies relating to psychoactive substances in England and elsewhere.

\section{Acknowledgements}

The authors would like to thank Emma Wincup, Katy Wright and Teela Sanders for their helpful comments on drafts of this article. We would also like to thank the two anonymous reviewers for their feedback and advice.

\section{Reference List}

Alcohol Policy UK (2015). Alcohol offender 'sobriety tag' scheme could go national. Retrieved 15 October 2015 from http://www.alcoholpolicy.net/2015/08/alcoholoffender-sobriety-tag-scheme-could-go-national.html .

Barton, A. (2011). Illicit drugs: use and control. Abingdon: Routledge.

Bauman, Z. (1998). Work, consumerism and the new poor. Buckingham: Open University Press.

BBC News (2009). Alcoholics could see benefits cut. BBC News, 14 April.

BBC News (2012). State must 'go further' to help addicts - Iain Duncan Smith. BBC News, 24 May.

BBC News (2014). Duncan Smith outlines plans for pre-paid benefits cards. BBC News, 29 September.

Bennett, T. and Holloway, K. (2005). Understanding drugs, alcohol and crime. Berkshire: Open University Press.

Berridge, V. (2013). Demons: our changing attitudes to alcohol, tobacco and drugs. Oxford: Oxford University Press.

Blair, T. (2011). Blaming a moral decline for the riots makes good headlines but bad policy. The Observer, 20 August.

Bottoms, A. (2006). Incivilities, offence and the social order in residential communities. In A.P. Simester and A. Von Hirsch (Eds), Incivilities: regulating offensive behaviour. Oxford: Hart, pp.239-280. 
Braithwaite, J. (1981). The myth of social class and criminality revisited. American Sociological Review, 46 (1), 36-57.

Cameron, D. (2011). Troubled families speech. Retrieved 16 October 2015 from: https://www.gov.uk/government/speeches/troubled-families-speech .

Crawford, A. (2010). Regulating civility, governing security and policing (dis)order under the conditions of uncertainty. In J. Blad, M. Hildebrandt, M. Rozemond, M. Schuilenburg and P. Van Calster (Eds), Governing security under the rule of law. The Hague: Eleven International, pp.9-35.

Department of Health (2016). UK Chief Medical Officers' Alcohol Guidelines Review. Retrieved 15 January 2016 from:

https://www.gov.uk/government/uploads/system/uploads/attachment data/file/48979 5/summary.pdf .

Department of Work and Pensions (DWP) (2013). Universal credit: local services support framework. Retrieved 16 October 2015 from:

https://www.gov.uk/government/uploads/system/uploads/attachment data/file/18139 5/uc-local-service-support-framework.pdf .

Department of Work and Pensions (DWP) (2015). Press release: benefits sanctions down as more people helped into work. Retrieved 14 October 2015 from:

https://www.gov.uk/government/news/benefit-sanctions-down-as-more-peoplehelped-into-work.

Donaldson, L. (2009a). Annual report of the Chief Medical Officer 2008 - on the state of public health. London: Department of Health.

Donaldson, L. (2009b). Guidance on the Consumption of Alcohol by Children and Young People. London: Department of Health.

Duke, K. (2006). Out of crime and into treatment? The criminalization of contemporary drug policy since 'Tackling drugs together'. Drugs: Education, Prevention and Policy, 13 (5), 409-415

Duke, K. (2013) 'From Crime to Recovery: The Reframing of British Drugs Policy?', Journal of Drug Issues, 43 (1) 39-55

Field, F. (1996). Britain's underclass: countering the growth. In R. Lister (Ed) Charles Murray and the underclass: the developing debate. London: IEA Health and Welfare Unit, pp.57-60.

Field, F. (2003). Neighbours from hell: the politics of behaviour. London: Politicos.

Hancock, J., Fearon, C., McLaughlin, H. and Fearon, B. (2012). Policing the drugs intervention programme: an exploratory study of the southern UK policing region. Policing. 6 (4), 431-442.

Harrison, M and Sanders, T (eds) (2014) Social Policies and Social Control: The Not so Big Society, Bristol: Policy Press.

Health and Social Care Information Centre (2013). Statistics on alcohol: England, 2013. Newport: Office for National Statistics.

Home Office (2012). News story: Ambitious new Alcohol strategy launched.

Retrieved 16 December 2015 from: https://www.gov.uk/government/news/ambitiousnew-alcohol-strategy-launched 
Hopkins, M. and Sparrow, P. (2006). Sobering up: arrest referrals and brief intervention for alcohol users in the custody suite. Criminology and Criminal Justice, 6 (4), 389-410.

House of Common Library (2012). Appendix 1: Recommendation from the 2002 Home Affairs Committee on Drug Policy. Retrieved 16 October 2015 from: http://www.publications.parliament.uk/pa/cm201213/cmselect/cmhaff/184/18411.htm Hucklesby, A., Eastwood, C., Seddon, T. and Spriggs, A. (2007). The evaluation of the restriction on bail pilot. Retrieved 16 October 2015 from:

http://webarchive.nationalarchives.gov.uk/20110220105210/rds.homeoffice.gov.uk/rd s/pdfs07/rdsolr0607.pdf .

Jewkes, Y. (2011). Media and crime. London: Sage.

Levine, H.G. (1978). The discovery of addiction: changing conceptions of habitual drunkenness in America. Journal of Studies on Alcohol, 39 (1), 493-506.

Lowe, P.K. and Lee, E.J. (2010). Advocating alcohol abstinence to pregnant women: some observations about British policy. Health, Risk and Society, 12 (4), 301-311.

McKeganey, N. (2014). Clear rhetoric and blurred reality: The development of a recovery focus in UK drug treatment policy and practice. International Journal of Drug Policy, 25 (5), 957-963.

McManus, S., Meltzer, H., Brugha, T., Bebbington, P. and Jenkins, R. (2009). Adult psychiatric morbidity in England, 2007: results of a household survey. Leeds: NHS Information Centre.

McSweeney, T. (2014). Calling time on 'alcohol-related' crime? Examining the impact of court-mandated alcohol treatment on offending using propensity score matching. Criminology and Criminal Justice, 15 (4), 464-483.Murray, C. (1996). The emerging British underclass. In R. Lister (Ed) Charles Murray and the underclass: the developing debate. London: IEA Health and Welfare Unit, pp.23-56.

Monaghan, M. (2012) The recent evolution of UK drug strategies: From maintenance to behaviour change? People, Place and Policy Online, 6 (1) 29-40

Monaghan, M. and Wincup, E. (2013) Work and the journey to recovery: Exploring the implications of welfare reform for methadone maintenance clients, International Journal of Drugs Policy, 24 (6) e81-6

Murray, C (1984) Losing Ground, New York: Harper Collins

Murray, C. (1996a) 'The emerging British underclass' in Lister, R. (ed) Charles Murray and the Underclass: The Developing Debate, London: IEA Health and Welfare Debate pp 23-53

Murray, C. (1996b) Underclass: the crisis deepens in Lister, R. (ed) Charles Murray and the Underclass: The Developing Debate, London: IEA Health and Welfare Debate pp 99-135

Newton, B., Meager, N., Bertram, C., Corden, A., George, A., Lalani, M., Metcalf, H., Rolfe, H., Sainsbury, R. and Weston, K. (2012). Work programme evaluation:

findings from the first phase of qualitative research on programme delivery.

Retrieved 16 October 2015 from:

https://www.gov.uk/government/uploads/system/uploads/attachment data/file/19332 4/821summ.pdf . 
Nutt, D. (2011). There is no such thing as a safe level of alcohol consumption. The Guardian, 7 March 2011.

Nutt, D., King, L.A., Saulsbury, W. and Blakemore, C. (2007). Development of a rational scale to assess the harm of drugs of potential misuse. The Lancet, 369 (9566), 1046-1053.

Nutt, D., King, L.A. and Phillips, L.D. (2010). Drug harms in the UK: a multi criteria decision analysis. The Lancet, 376 (9752), 1558-1565

Patrick, R. (2012) 'Work as the primary 'duty' of the responsible citizen: a critique of this work centred approach', People, Place and Policy Online, 6 (1)

Prideaux, S. J. (2010). The welfare politics of Charles Murray are alive and well in the UK. International Journal of Social Welfare, 19 (3) 293-302.

Prison Reform Trust (2013). Prison: the facts. Retrieved 16 October 2015 from: http://www.prisonreformtrust.org.uk/Portals/0/Documents/Prisonthefacts.pdf .

Reuter, P. and Stevens, A. (2007). An analysis of UK drug policy: a monograph prepared for the UK drug policy commission. London: United Kingdom Drug Policy Commission.

Rolles, S. and Measham, F. (2011) 'Questioning the method and utility of ranking drug harms in drug policy, International Journal of Drug Policy, 22 (4) 243-46

Science and Technology Committee (2012), 'Alcohol guidelines', UK Parliament: London.

Schrad, M.L. (2010) The Political Power of Bad Ideas: Networks, Institutions and the Global Prohibition Wave, Oxford: Oxford University Press

Seddon, T. (2006). Drugs, crime and social exclusion: social context and social theory in British drugs-crime research. British Journal of Criminology, 46 (4), 680 703.

Seddon, T. (2010). A history of drugs: drugs and freedom in the liberal age.

Abingdon: Routledge.

Seddon, T., Ralphs, R. and Williams, L. (2008) Risk, security and the 'criminalization' of British drug policy, British Journal of Criminology, 48(4) 818-34

Stevens, A. and Measham, F. (2014). The drug policy ratchet: why do sanctions for new psychoactive drugs typically only go up? Addiction, 109 (8), 1226-1232.

Sutherland, E.H. (1940). White collar criminality. American Sociological Review, 5 (1), 1-12.

The Guardian (2014). 'Sobriety tags' to be worn by offenders of alcohol-linked crime in pilot scheme. The Guardian, 31 July.

Thom, B. (1999). Dealing with drink. London: Free Association.

UK Government (2008). Drugs: protecting families and communities. The 2008-2018 drug strategy. London: Home Office

UK Government (2010). Drug strategy 2010. London: Home Office.

UK Government (2012). The Government's alcohol strategy. London: Home Office.

UK Government (2013). Drug strategy annual review. London: Home Office. 
UK Government (2015). Petition: make the production, sale and use of cannabis legal. Retrieved 16 October 2015 from:

https://petition.parliament.uk/petitions/104349 .

Valverde, M. (1998). Diseases of the will: alcohol and the dilemmas of freedom. Cambridge: Cambridge University Press.

Wacquant, L. (2009). Punishing the poor: the neoliberal government of social insecurity. London: Duke University Press.

Wakeman, S. (2015) The moral economy of Heroin in 'Austerity Britain', Critical Criminology, advanced access http://link.springer.com/article/10.1007/s10612-0159312-5/fulltext.html

Wardle, I. (2012). Five years of recovery: December 2005 to December 2010 - from challenge to orthodoxy. Drugs: Education, Prevention \& Policy 19(4): 294-298.

Wincup, E. (2011) Carrots and sticks: problem drug users and welfare reform. Criminal Justice Matters, 84, 1, 22-23

Wincup, E, (2014) 'Thoroughfares, crossroads and cul-de-sacs: Drug testing of welfare recipients', International Journal of Drug Policy, 25(5): 1031-1037

Wintour, P. (2015). Obese people and drug users who refuse treatment could have benefits cut. The Guardian, 29 July.

Yeomans, H. (2014) Alcohol and Moral Regulation: Public Attitudes, Spirited Measures and Victorian Hangovers', Bristol: Policy Press. 
There are no conflicts of interest to report.

\footnotetext{
i England is chosen as the focus of our analysis as certain aspects of drugs and alcohol policy are the responsibility of the devolved administrations.
} 